\title{
A circumaortic left renal vein
}

\author{
Mototsugu Matsunaga, Tomoyuki Ushijima, Masaru Fukahori, Keisuke Miwa
}

Multidisciplinary Treatment Cancer Center, Kurume University Hospital, Kurume, Fukuoka, Japan

\section{Correspondence to} Dr Mototsugu Matsunaga, mmandmacgyver@yahoo.co.jp

Accepted 31 August 2015

\section{DESCRIPTION}

A middle-aged man who underwent a thorough examination for epigastric pain was diagnosed with unresectable pancreatic cancer and referred to our department. A circumaortic left renal vein ${ }^{1}$ was incidentally detected on abdominal CT (figures 1 and 2). The ventral branch of the left renal vein (red arrow) ran between the aorta and the superior mesenteric artery, and opened into the inferior vena cava. The dorsal branch of the left renal vein (blue arrow) ran obliquely downward between the aorta and the vertebral body, and opened into the inferior vena cava.

In cases of a circumaortic left renal vein, which is a developmental anomaly of the left renal vein, two veins arising from the left renal vein trunk surround the aorta. ${ }^{1}$ This anomaly infrequently causes haematuria, proteinuria ${ }^{2}$ and massive haemorrhage during surgery; therefore, recognition of its presence is extremely important to avoid complications.
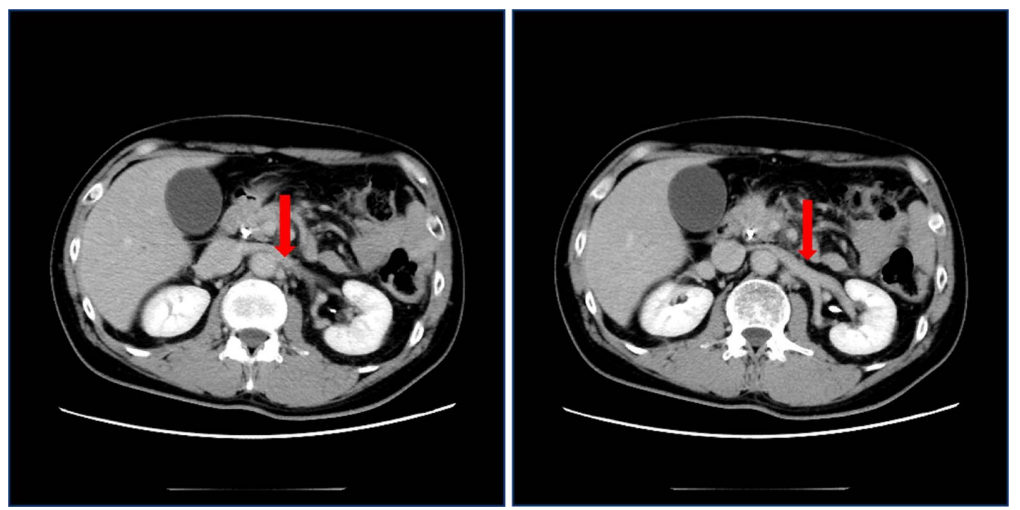

Figure 1 Abdominal CT scans showing the ventral branch of the left renal vein (red arrow) running between the aorta and the superior mesenteric artery, and opening into the inferior vena cava.
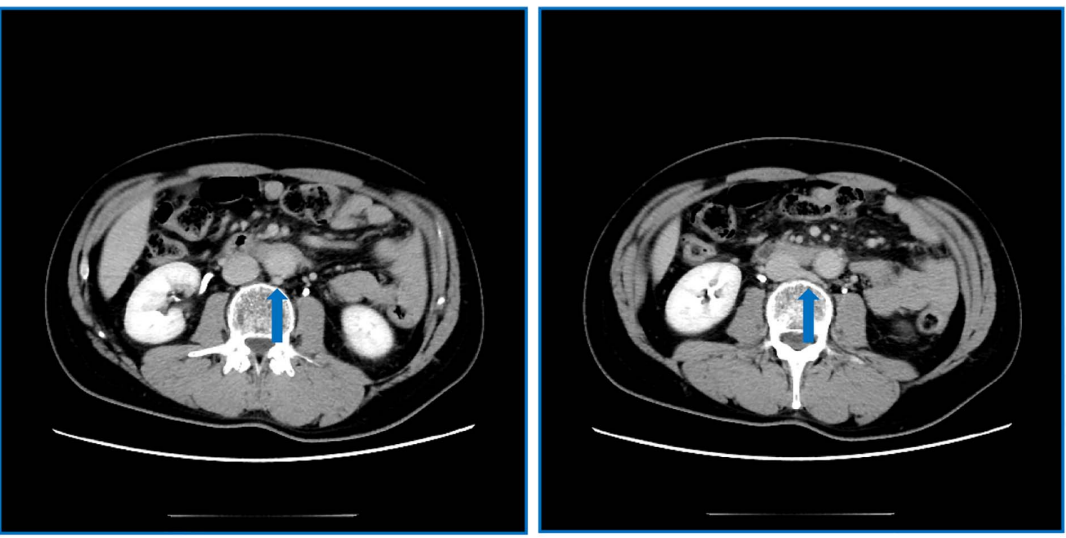

Figure 2 Abdominal CT scans showing the dorsal branch of the left renal vein (blue arrow) running obliquely downward between the aorta and the vertebral body, and opening into the inferior vena cava. 


\section{REFERENCES}

1 Chuang VP, Mena CE, Hoskins PA. Congenital anomalies of the inferior vena cava. Review of embryogenesis and presentation of a simplified classification. $\mathrm{Br} J$ Radiol 1974;47:206-13.
2 Karaman B, Koplay M, Ozturk E, et al. Retroaortic left renal vein: multidetector computed tomography angiography findings and its clinical importance. Acta Radiol 2007;48:355-60.

Copyright 2015 BMJ Publishing Group. All rights reserved. For permission to reuse any of this content visit http://group.bmj.com/group/rights-licensing/permissions.

BMJ Case Report Fellows may re-use this article for personal use and teaching without any further permission.

Become a Fellow of BMJ Case Reports today and you can:

- Submit as many cases as you like

- Enjoy fast sympathetic peer review and rapid publication of accepted articles

- Access all the published articles

- Re-use any of the published material for personal use and teaching without further permission

For information on Institutional Fellowships contact consortiasales@bmjgroup.com

Visit casereports.bmj.com for more articles like this and to become a Fellow 